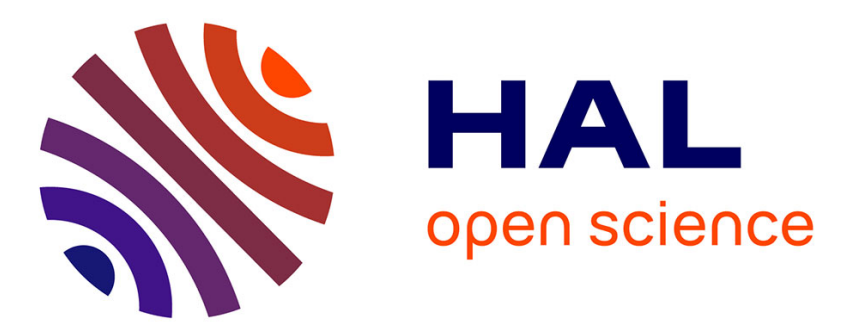

\title{
Pathological effects of the microsporidium Nosema ceranae on honey bee queen physiology (Apis mellifera)
}

Cédric Alaux, Morgane Folschweiller, Cynthia Mcdonnell, Dominique Beslay, Marianne Cousin, Claudia Dussaubat, Jean-Luc Brunet, Yves Le Conte

\section{- To cite this version:}

Cédric Alaux, Morgane Folschweiller, Cynthia Mcdonnell, Dominique Beslay, Marianne Cousin, et al.. Pathological effects of the microsporidium Nosema ceranae on honey bee queen physiology (Apis mellifera). Journal of Invertebrate Pathology, 2011, 106 (3), pp.380-385. 10.1016/j.jip.2010.12.005 . hal-02651105

\section{HAL Id: hal-02651105 \\ https://hal.inrae.fr/hal-02651105}

Submitted on 29 May 2020

HAL is a multi-disciplinary open access archive for the deposit and dissemination of scientific research documents, whether they are published or not. The documents may come from teaching and research institutions in France or abroad, or from public or private research centers.
L'archive ouverte pluridisciplinaire HAL, est destinée au dépôt et à la diffusion de documents scientifiques de niveau recherche, publiés ou non, émanant des établissements d'enseignement et de recherche français ou étrangers, des laboratoires publics ou privés. 


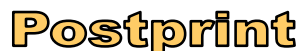

Version définitive du manuscrit publié dans / Final version of the manuscript published in : Journal of Invertebrate Pathology, 2011, vol.106, n³, DOI : 10.1016/j.jip.2010.12.005

\section{Pathological effects of the microsporidium Nosema ceranae on honey bee queen physiology (Apis mellifera)}

Cédric Alaux $x^{\mathrm{a}}$, Morgane Folschweiller ${ }^{\mathrm{a}}$, Cynthia McDonnell ${ }^{\mathrm{a}}$, Dominique Beslay ${ }^{\mathrm{a}}$, Marianne Cousin ${ }^{\mathrm{b}}$, Claudia Dussaubat ${ }^{\mathrm{a}}$, Jean-Luc Brunet ${ }^{\mathrm{b}}$, Yves Le Conte ${ }^{\mathrm{a}}$

${ }^{a}$ INRA, UMR 406 Abeilles et Environnement, Laboratoire Biologie et Protection de l'abeille, Site Agroparc, Domaine Saint-Paul, 84914 Avignon, France

${ }^{\mathrm{b}}$ INRA, UMR 406 Abeilles et Environnement, Laboratoire de Toxicologie Environnementale, Site Agroparc, Domaine Saint-Paul, 84914 Avignon, France

\section{Corresponding author:}

Cédric Alaux

INRA, UMR 406 Abeilles et Environnement

Laboratoire Biologie et Protection de l'abeille

Domaine Saint-Paul

84914 Avignon, France

Email : cedric.alaux@avignon.inra.fr

Tel : (33) (0)4 32722618

Fax : (33) (0)4 32722602

\begin{abstract}
Nosema ceranae, a microsporidian parasite originally described in the Asian honey bee Apis cerana, has recently been found to be cross-infective and to also parasitize the European honey bee Apis mellifera. Since this discovery, many studies have attempted to characterize the impact of this parasite in Apis mellifera honey bees. Nosema species can infect all colony members, workers, drones and queens, but the pathological effects of this microsporidium has been mainly investigated in workers, despite the prime importance of the queen, who monopolizes the reproduction and regulates the cohesion of the society via pheromones. We therefore analyzed the impact of $N$. ceranae on queen physiology. We found that infection by $N$. ceranae did not affect the fat body content (an indicator of energy stores) but did alter the vitellogenin titer (an indicator of fertility and longevity), the total antioxidant capacity and the queen mandibular pheromones, which surprisingly were all significantly increased in Nosema-infected queens. Thus, such physiological changes may impact queen health, leading to changes in pheromone production, that could explain Nosema-induced supersedure (queen replacement).
\end{abstract}


Version définitive du manuscrit publié dans / Final version of the manuscript published in : Journal of Invertebrate Pathology, 2011, vol.106, n³, DOI : 10.1016/j.jip.2010.12.005

Keywords: Nosema ceranae; honey bee queen; Apis mellifera; vitellogenin; queen mandibular pheromones; antioxidant capacity

\section{Introduction}

Microsporidia from the genus Nosema are intracellular parasites that infect a variety of insect taxonomic orders (Becnel and Andreadis, 1999). In honey bees, nosemosis is a major disease affecting adults and caused by the proliferation of Nosema spores in midgut epithelial cells after spores are ingested through contaminated food or comb and cleaning activity (Webster, 1993). After the initial infection, millions of spores can be found within a few days in the midgut (Bailey and Ball, 1991), which causes a reduction in the honey bee life span (Higes et al., 2007a; Malone et al., 1995; Rinderer and Sylvester, 1978; Paxton et al., 2007). Currently, two microsporidian parasites have been described from honey bees: N. apis (Zander, 1909) and N. ceranae (Fries et al., 1996) isolated from the European (Apis mellifera) and the Asian honey bee (Apis cerana), respectively. Recently, natural infections of N. ceranae in Apis mellifera have been found across the world (see Fries (2010) for a review). This emergent pathogen of the European honey bee is believed to be more virulent than $N$. apis (Paxton et al., 2007; Higes et al., 2007a) and to be one of the causes of colony collapse, notably in Spain (Higes et al., 2008). However, a recent study demonstrated similar virulence between both Nosema species (Forsgren and Fries, 2010); thus, virulence might actually depend on honey bee race or regional climate (Higes et al., 2010).

To date, most of the studies investigating the pathological effects of $N$. ceranae were performed in workers, but $N$. ceranae can also parasitize the queen and induce similar tissue lesions (Higes et al., 2009). While both workers and the queen can be infected, the consequences for the hive could be very different. Because she monopolizes reproduction and maintains colony homeostasis by continuously producing pheromones (Slessor et al., 2005), a queen weakened by $N$. ceranae infection might compromise the renewal and the stability of worker population. Accordingly, queen quality is of primary importance. In addition, according to beekeepers, 'poor queens' are estimated to be the major cause of the actual colony losses (van Engelsdorp et al., 2008). Data on the pathology of N. apis in queens are available. For example, infected queens have decreased ovary development, which can lead to infertility (Fyg, 1964; Liu, 1992), and are more often superseded (process by which an old or failing queen is replaced) (Farrar, 1947; Furgala, 1962 but see Czekonska, 2000). However, the pathological effects of $N$. ceranae, a newly emerging pathogen of European honey bees, remained to be studied in queens.

There are many measures that can serve as parameters for estimating the effects of $N$. ceranae on queen health. Vitellogenin $(\mathrm{Vg})$ is a yolk protein taken up by developing oocytes and associated to egg 


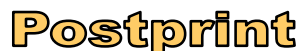

Version définitive du manuscrit publié dans / Final version of the manuscript published in : Journal of Invertebrate Pathology, 2011, vol.106, n³, DOI : 10.1016/j.jip.2010.12.005

production in queens (Engels, 1974; Tanaka and Hartfelder, 2004) but also has antioxidant functions that protect bees from oxidative stress and enhance longevity (Corona et al., 2007; Seehuus et al., 2006). Therefore, the hemolymph titer of $\mathrm{Vg}$, which is synthesized in the fat body, the main site of energy storage (Ricks and Vinson, 1972; Toth and Robinson, 2005), is as an indicator of queen fertility and longevity. The proper functioning of the colony is regulated by different pheromones, notably produced and transmitted by the queen. The main one is the queen mandibular pheromone (QMP), which stimulates queen attendance by workers, inhibits worker ovary development and regulates worker behavioral maturation (Slessor et al., 2005). Because they are both important for the queen health and colony organization, we determined the effects of $N$. ceranae infection on these physiological parameters. In addition, due to the energetic stress induced by $N$. ceranae (Mayack and Naug, 2009), we measured the total antioxidant capacity of queens. Knowing the lethal effects of this parasite on workers, we hypothesized that we would observe a reduced level of most of those physiological parameters in queens infected with $N$. ceranae compared to non-infected queens.

\section{Materials and Methods}

\subsection{Honey bee queen rearing}

Experiments were performed in Avignon (France) with local hybrid colonies (A. m. ligustica/A. m. mellifera). Queens were reared according to standard beekeeping methods (Laidlaw and Page, 1997). However, young larvae used for the queen grafting originated from the same colony to reduce genetic variation and thus potential variation between control and Nosema treatments regarding the physiological parameters that we analyzed, especially pheromones (Plettner et al., 1997; Pankiw et al., 1996).

Four days before hatching, queen cells were removed from their hive and placed individually in a cage at $34^{\circ} \mathrm{C}$ and $60 \% \mathrm{RH}$ with 30 one day-old bees, which were obtained from honey combs containing last-stage pupae removed from the source colonies used for queen rearing. Bees were fed ad libitum with water, candy (30\% honey, $70 \%$ powdered sugar) and pollen. Since $N$. ceranae can be found in pollen (Higes et al., 2007b) and honey (Chauzat et al., 2007), before feeding the bees, we checked under microscope that both pollen and honey were free of microspores. The queens emerged and were kept in those cages.

Nosema count in ventriculi, lipid stores in fat bodies, vitellogenin titer in hemolymph and QMP levels in heads were all analyzed in the same queens, while total antioxidant capacity in the whole abdomen was determined in another set of queens. 


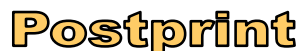

Version définitive du manuscrit publié dans / Final version of the manuscript published in : Journal of Invertebrate Pathology, 2011, vol.106, n³, DOI : 10.1016/j.jip.2010.12.005

\section{2. $N$. ceranae infection}

Queens were infected with $N$. ceranae at emergence and collected at day 8 to analyze the pathological effects of the microsporidia. This age was chosen since queens usually start their mating flights one week after emergence. To infect each queen with the same dose of spores when starting the experiments, they were fed individually as in Malone and Gatehouse (1998) with $2 \mu \mathrm{l}$ of a freshly prepared $50 \%$ sucrose solution containing 200,000 spores of $N$. ceranae. Similar spore number is known to cause an infection in queens (Higes et al., 2009). Control queens were fed with a sucrose solution.

Spores were isolated from a colony infected with $N$. ceranae. The digestive tract of individual bees was dissected and crushed in distilled water, then the suspension was filtered and centrifuged to collect the spores. The identification of $N$. ceranae was confirmed by standard PCR amplification and sequencing of the PCR results as in Alaux et al. (2010). The spore concentration of the feeding solution and the level of Nosema infection at the end of the experiment were determined by counting with a haemocytometer.

\subsection{Histological analysis of lipid stores in fat bodies}

The lipid stores in the fat bodies were determined using the Oil Red O staining protocol. This method has proven to be efficient in detecting differences in lipid content in worker bees (Toth and Robinson, 2005). We followed the same procedure by removing the abdomen of the queens and dissecting out the sternites 3 to 7 . This piece of cuticle with the fat bodies attached was rubbed onto a slide, which was then fixed with $10 \%$ formaldehyde, and washed with $60 \%$ isopropanol. The slide was then stained with Oil Red $\mathrm{O}$ for 15 minutes and washed with water. The stained tissue was observed under microscope at $\mathrm{x} 400$ and 10 photographic pictures of each slides were taken using a CANON Powershot A650 digital camera. Lipid content was quantified by automatically counting red pixels with Adobe Photoshop version 7.0.

\subsection{Quantification of vitellogenin titers}

Vitellogenin quantification in queens was determined by SDS-PAGE, following the standard method commonly used for honey bee workers (Lin et al., 1999; Amdam et al., 2006; Nelson et al., 2007). After puncturing the abdomen between the third and fourth tergite, hemolymph was extracted by microcapillary (Hirschmann Ringcaps). Samples that were contaminated with gut content were discarded. Hemolymph $(1 \mu \mathrm{l})$ was diluted in $50 \mu \mathrm{l}$ PBS (phosphate buffered saline) and separated by SDS-polyacrylamide gel electrophoresis with a 3\% acrylamide stacking gel and $8 \%$ separation gel using standard methods. A $\beta$-galactosidase standard (Sigma-Aldrich) was also loaded in equal amount on all gels to control for variation between gels and densitometrically quantification of vitellogenin (single band of $180 \mathrm{kDa}$ ) (Wheeler and Kawooya, 1990; Lin et al., 1999). Protein molecular weight markers ranging from 70 to $250 \mathrm{kDa}$ (Bio-Rad, France) were used and electophoresis was run at $220 \mathrm{~V}$ 


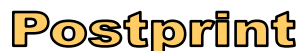

Version définitive du manuscrit publié dans / Final version of the manuscript published in : Journal of Invertebrate Pathology, 2011, vol.106, n³, DOI : 10.1016/j.jip.2010.12.005

at $4^{\circ} \mathrm{C}$. After staining the gels with Commassie Brilliant Blue, band intensities were densitometrically measured with the software Image-J 1.36.

\subsection{Total antioxidant capacity}

The total antioxidant capacity in queens was determined using the antioxidant assay kit (\#709001, Cayman chemical, USA) following the kit instruction as in Williams et al. (2008). Whole abdomens were individually homogenized at $4^{\circ} \mathrm{C}$, using a TissueLyser (Qiagen, Courtaboeuf, France), in $20 \%$ (w/v) ice-cold phosphate buffer ( $5 \mathrm{mM}$ potassium phosphate, $0.9 \%$ osdium chloride, $0.1 \%$ glucose, $\mathrm{pH}$ 7.4). The homogenates were then centrifuged at $15,000 \mathrm{~g}$ for $15 \mathrm{~min}$ at $4^{\circ} \mathrm{C}$. The supernatant was diluted in the phosphate buffer $(1 / 100)$ and used for analysis of total antioxidant activity. The capacity of the antioxidants in $10 \mu \mathrm{l}$ of the solution to inhibit the oxidation of ABTS $^{\circledR}$ (2,2'-Azino-di-[3ethylbenzthiazoline sulphonate]) to $\mathrm{ABTS}^{+\circledast}$ was assessed. The amount of $\mathrm{ABTS}^{+\circledR}$ produced was determined by reading the absorbance at $750 \mathrm{~nm}$. Then, the total antioxidant capacity was compared to trolox standards and quantified as $\mathrm{mM}$ trolox equivalents.

\subsection{Pheromone analysis}

The analysis of queen pheromone components (9-ODA, HOB, HVA, 9-HDA) was performed following the same procedure published by Maisonnasse et al. (2010). Briefly, queen heads were stored at $-20^{\circ} \mathrm{C}$ before chemical analysis of the QMP components. Pheromone compounds were extracted by crushing individual heads in $200 \mu \mathrm{l}$ of methanol and $100 \mu \mathrm{l}$ of decanoic acid $(250 \mathrm{ng} / \mu \mathrm{l}$; internal standard) for 2 minutes on ice. $20 \mu \mathrm{l}$ of the supernatant was collected and concentrated under nitrogen stream and then derivatized with $5 \mu 1$ of bistrimethylsilyltrifluoroacetamide. The solution was homogenized and left at room temperature for $40 \mathrm{~min}$. The derivatized sample was then diluted in 100 $\mu l$ of isohexane and $1 \mu \mathrm{l}$ of the solution was injected into a fast gas chromatograph (Shimadzu 2014, Japan). The samples were injected in split mode. Hydrogen was used as carrier gas. Oven temperature was set at $100^{\circ} \mathrm{C}$, then $100^{\circ} \mathrm{C}$ to $200^{\circ} \mathrm{C}$ at $40^{\circ} \mathrm{C} \mathrm{min}^{-1}$ and $200^{\circ} \mathrm{C}$ to $250^{\circ} \mathrm{C}$ at $10^{\circ} \mathrm{C} \mathrm{min}^{-1}$ and held at $250^{\circ} \mathrm{C}$ for $2 \mathrm{~min}$. Identification and quantification of HOB, 9ODA, HVA, 9HDA were based on retention times of synthetic compounds (Sigma-Aldrich, France and PheroTech, Canada). The confirmation of QMP compounds was done by mass spectrometer (Shimadzu CP2010, Japan).

Since the data were not normally distributed, Nosema effects on the different parameters of queen physiology were determined using Mann-Whitney U tests. In order to determine whether some of the measured physiological parameters (fat body content, Vg and QMP) were correlated, we performed a correlation analysis including all queens. 


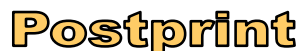

Version définitive du manuscrit publié dans / Final version of the manuscript published in : Journal of Invertebrate Pathology, 2011, vol.106, n³, DOI : 10.1016/j.jip.2010.12.005

\section{Results}

After 8 days, the level of Nosema infection was analyzed in experimentally infected and control queens ( $n=8$ for both). In infected queens, the mean number of Nosema spores per queen was 18.2 millions $\left( \pm 6 \times 10^{6}\right)$. No spore was detected in control queens, except in 2 queens that were infected with 40,000 and 20,000 spores, which is 5 and 10 times lower than the dose use to infect the experimental queens.

Regarding the pathological effects of $N$. ceranae, the microspore infection induced a slight decrease in the fat bodies lipid staining but the difference with control queens was not significant (Fig. 1A). However, the Vg titer increased by around $58 \%$ when queens were infected with $N$. ceranae, which was significantly higher than control queens (Fig. 1B). Similarly, the total antioxidant capacity significantly augmented in infected queens (Fig. 1C).

Analysis of queen heads revealed that the QMP components 9-ODA, HOB and 9-HDA were present in both control and parasitized queens (Fig. 2), but HVA was not detected since queens were virgin (Ledoux et al., 2001). However, all QMP components, except HOB, were significantly higher in $N$. ceranae infected queens compared to control (Fig. 2).

The correlation analysis performed on the measured physiological parameters (fat body content, $\mathrm{Vg}$ and QMP) revealed a significant negative correlation between the amount of lipid stores in the fat bodies and the $\mathrm{Vg}$ titer (Table 1). No significant correlation was found between the others physiological parameters.

\section{Discussion}

In this study, we experimentally infected queens with $N$. ceranae to determine whether microsporidia affects the queen physiology and health (the minor infection observed in two control queens probably came from spores ingested by chewing the wax capping at emergence (Malone and Gatehouse, 1998)). Based on the lethal effects of $N$. ceranae in workers and the similar lesions induced in queens (Antúnez et al., 2009), we expected a weakening of queen physiology. However, our results clearly demonstrated that $N$. ceranae infection actually boosted the main physiological functions of the queens.

Since recent studies demonstrated that Nosema parasitism cause a nutritional stress in workers (Mayack and Naug, 2009; Naug and Gibbs, 2009; Alaux et al., 2010) and a reduction in fat body content in winter bees (Bailey and Ball, 1991), a loss of energy store could be expected in queens. However, although slightly decreased in infected queens after one week, the lipid content in fat bodies (indicator of nutritional status) was not different from control queens, suggesting that queens might be able to compensate for the nutrition stress induced by Nosema by increasing their food demand to workers and thus their food consumption. However, we cannot exclude the possibility that in the long- 


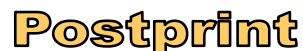

Version définitive du manuscrit publié dans / Final version of the manuscript published in : Journal of Invertebrate Pathology, 2011, vol.106, n³, DOI : 10.1016/j.jip.2010.12.005

term the decrease in lipid stores may become more pronounced. Alternatively, the higher Vg titer observed in infected queens could explain the slight decrease in fat body content, since this hormone is synthesized in this tissue (Pan et al., 1969). An increase in Vg synthesis could lead to the impoverishment of its site of production (fat bodies), as indicated by the negative correlation between lipid store and Vg level (Table 1).

Workers and queens develop from the same genome, but opposing responses to $N$. ceranae were observed regarding $\mathrm{Vg}$ production. Contrary to the $\mathrm{Vg}$ decrease observed in infected workers (Antúnez et al., 2009), N. ceranae triggers the increase of Vg synthesis in queens. The lower amount of $\mathrm{Vg}$ in parasitized workers might explain their shorter lifespan, taking into account the positive effect of Vg activity on bee longevity (Seehuus et al., 2006). Alternatively, since Vg is present at lower levels in old foragers compared to young nurses (Page and Amdam, 2007), and because Nosema causes a precocious onset of foraging (transition from nurse to forager tasks) (Wang and Moeller, 1970), the decrease in $\mathrm{Vg}$ might simply reflect the precocious forager profile of infected bees compared to control bees. Thus, this response could be interpreted as a mechanism by which infected workers remove themselves from the hive in order to decrease pathogen load within the colony (Kralj and Fuchs, 2010). However, compared to the loss of workers, queen replacement is more costly and critical to the colony, and thus queens may have evolved to cope with parasite infection. Vitellogenin function is pleiotropic and has been shown to play a role in maintaining the population of functioning hemocytes in honey bee workers (Amdam et al., 2004) and to be involved in the regulation of innate immune response against bacteria and fungi in fishes (Liu et al., 2009; Li et al., 2008; Tong et al., 2010; Li et al., 2009) and mosquitos (Raikhel et al., 2002). This latter function has not been characterized in honey bees but seems unlikely in this case as the observed spore loads seen in queens here were similar to those of workers experimentally infected with the same amount of Nosema microspores in a previous study (Alaux et al., 2010) and this study). Similar rates of infection with $N$. apis were also found in workers and queens (Webster et al., 2004). Thus, there is no correlation between the spore loads and the Vg level. Although we cannot exclude the possibility that the increase in Vg level reflects an immune response against an increase in bacterial or viral populations (Bailey et al. 1983) associated with Nosema infection, the most direct explanation supports a primary effect of Nosema on host physiology. Indeed, $N$. ceranae is strictly dependant on host energy for its development and germination (Keeling and Fast, 2002; Cornman et al., 2009), which would lead to an increase in host metabolism and oxidative stress. In that case, the increase in Vg production observed in infected queens might be a response to the energetic stress caused by the spore population, since $\mathrm{Vg}$ is able to reduce oxidative stress by scavenging free radicals and therefore prolong the lifespan of bees (Seehuus et al., 2006). The elevated Vg titer would suggest a higher capacity to resist oxidative stress, which was demonstrated by higher total antioxidant enzyme activity in infected queens (Fig. 1C). Despite this protective response, Nosema-infected queens seems to have a shorter lifespan compared 


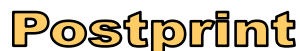

Version définitive du manuscrit publié dans / Final version of the manuscript published in : Journal of Invertebrate Pathology, 2011, vol.106, n³, DOI : 10.1016/j.jip.2010.12.005

to healthy queens (Higes et al., 2009), suggesting that they are not able to cope with the physiological stress of Nosema over the long-term.

Our chemical analysis demonstrated that Nosema can significantly modify pheromone production in queens; similar results were found in workers in which Nosema parasitism altered the production of the pheromone ethyl oleate (Dussaubat et al., 2010). Based on the observation that Nosema-infected queens are more likely to be superseded (Farrar, 1947; Furgala, 1962), Butler (1958) suggested that infected queens produced lower amount of pheromones. In fact, we found that infected queens produced higher quantities of QMP compared to healthy queens. Richard et al. (2007) found that the QMP profile changes according to insemination quantity, with virgin or single-drone inseminated queens producing higher amounts of 9-ODA and 9-HDA compared to mated or multi-drone inseminated queens, respectively. In our study, the QMP compounds, 9-ODA and 9-HAD, were higher in infected queens, suggesting that elevated levels of QMP are a hallmark of poorly fertile or sick queens. It is not known how those pheromone changes would affect the queen-worker relationships, but some data indicate that queens with lower amount of QMP are more attractive and groomed than queens with higher amount of QMP (Richard et al., 2007), suggesting that sick queens would be less attended by workers.

Physiological stress and changes in QMP might affect the ability of queens to mate and/or to be attractive for drones. In the field, the presence of spores in mated queens can lead to a Nosemainduced supersedure, in which the infected queen is replaced by a new, presumably healthy queen (Farrar, 1947; Furgala, 1962). The QMP modification induced by N. ceranae, coupled with the ability of workers to detect and respond differently to the pheromone changes (Richard et al., 2007) might explain the reports of Nosema-induced supersedure. However, those assumptions remain to be tested in the field and represent the next step to further understanding the consequences of the queen pathology on its ability to mate and on the colony fate.

\section{Acknowledgments}

We thank A. Maisonnasse and D. Crauser for their assistance with queen rearing and members of the lab and anonymous referees for comments that improve the manuscript. This work was funded by a BEEDOC grant (FP7, RTD REG/E.4(2009)D/561221). C. Alaux was supported by an INRA young researcher position (INRA SPE department), C. McDonnell by the BEEDOC grant and C. Dussaubat by a CONICYT/French Ambassy of Chile grant. 


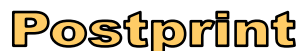

Version définitive du manuscrit publié dans / Final version of the manuscript published in : Journal of Invertebrate Pathology, 2011, vol.106, n³, DOI : 10.1016/j.jip.2010.12.005

\section{References}

Alaux, C., Brunet, J. L., Dussaubat, C., Mondet, F., Tchamitchan, S., Cousin, M., Brillard, J., Baldy, A., Belzunces, L. P., Le Conte, Y., 2010. Interactions between Nosema microspores and a neonicotinoid weaken honeybees (Apis mellifera). Environ. Microbiol. 12, 774-782.

Amdam, G. V., Norberg, K., Page, R. E., Erber, J., Scheiner, R., 2006. Downregulation of vitellogenin gene activity increases the gustatory responsiveness of honey bee workers (Apis mellifera). Behav. Brain Res. 169, 201-205.

Amdam, G. V., Simões, Z. L. P., Hagen, A., Norberg, K., Schrøder, K., Mikkelsen, Ø., Kirkwood, T. B. L., Omholt, S. W., 2004. Hormonal control of the yolk precursor vitellogenin regulates immune function and longevity in honeybees. Exp. Gerontol., 39, 767-773.

Antúnez, K., Martín-Hernández, R., Prieto, L., Meana, A., Zunino, P., Higes, M., 2009. Immune suppression in the honey bee (Apis mellifera) following infection by Nosema ceranae (Microsporidia). Environ.1 Microbiol. 11, 2284-2290.

Bailey, L., Ball, B. V., 1991. Honey Bee Pathology, second ed. Academic Press, London.

Bailey, L., Ball, B. V., Perry J.N., 1983. Association of viruses with two protozoal pathogens of the honey bee. Ann. Appl. Biol. 103, 13-20.

Becnel, J. J., Andreadis, T. G., 1999. Microsporidia in insect, in: Wittner, M., Weiss, L. M. (Eds.), The Microsporidia and Microsporidiosis. ASM Press, Washington, DC, pp. 447-501.

Butler, C. G., 1958. Queen supersedure and swarming, in: Central Association of Beekeepers, pp. 12. Ilford, England.

Chauzat, M. P., Higes, M., Martin-Hernandez, R., Aranzazu, M., Cougoule, N., Faucon, J. P., 2007. Presence of Nosema ceranae in French honey bee colonies. J. Apicult. Res. 46, 127-128.

Cornman, R. S., Chen, Y. P., Schatz, M. C., Street, C., Zhao, Y., Desany, B., Egholm, M., Hutchison, S., Pettis, J. S., Lipkin, W. I., Evans, J. D., 2009. Genomic analyses of the microsporidian Nosema ceranae, an emergent pathogen of honey bees. PLoS Pathogy 5, e1000466.

Corona, M., Velarde, R. A., Remolina, S., Moran-Lauter, A., Wang, Y., Hughes, K. A., Robinson, G. E., 2007. Vitellogenin, juvenile hormone, insulin signaling, and queen honey bee longevity. Proc. Natl. Acad. Sci. USA 104, 7128-33.

Czekonska, K., 2000. The influence of Nosema apis on young honeybee queens and transmission of the disease from queens to workers. Apidologie 31, 701-706.

Dussaubat, C., Maisonnasse, A., Alaux, C., Tchamitchan, S., Brunet, J. L., Plettner, E., Belzunces, L. P., Le Conte, Y., 2010. Nosema spp. infection alters pheromone production in honey bees (Apis mellifera). J. Chem. Ecol. 36, 522-525.

Engels, E., 1974. Occurrence and significance of vitellogenins in female castes of social Hymenoptera. Am. Zool. 14, 1229-1237.

Farrar, C. L., 1947. Nosema losses in package bees as related to queen supersedure and honey yields. J. Econ. Entomol. 40, 333-338. 


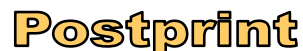

Version définitive du manuscrit publié dans / Final version of the manuscript published in : Journal of Invertebrate Pathology, 2011, vol.106, n³, DOI : 10.1016/j.jip.2010.12.005

Forsgren, E., Fries, I., 2010. Comparative virulence of Nosema ceranae and Nosema apis in individual European honey bees. Vet. Parasitol. 170, 212-217.

Fries, I., 2010. Nosema ceranae in European honey bees (Apis mellifera). J. Invertebr. Pathol. 103, S73-S79.

Fries, I., Feng, F., Da Silva, A., Slemeda, S. B., Pieniazek, N. J., 1996. Nosema ceranae n. sp. (Microspora, Nosematidae), morphological and molecular characterization of a microsporidian parasite of the Asian honey bee Apis cerana (Hymenoptera, Apidae). Eur. J. Protistol. 32, $356-365$

Furgala, B., 1962. The effect of the intensity of Nosema inoculum on queen supersedure in the honey bee, Apis mellifera Linnaeus. J. Insect Pathol. 4, 429-432.

Fyg, W., 1964. Anomalies and diseases of the queen honey bee. Ann. Rev. Entomol. 9, 207-224.

Higes, M., Garcia-Palencia, P., Botias, C., Meana, A., Martin-Hernandez, R., 2010. The differential development of microsporidia infecting worker honey bee (Apis mellifera) at increasing incubation temperature. Environ. Microbiol. Reports in press, DOI: 10.1111/j.17582229.2010.00170.x

Higes, M., Garcia-Palencia, P., Martin-Hernandez, R., Meana, A., 2007a. Experimental infection of Apis mellifera honeybees with Nosema ceranae (Microsporidia). J. Invertebr. Pathol. 94, 2117.

Higes, M., Martin-Hernandez, R., Botias, C., Bailon, E. G., Gonzalez-Porto, A. V., Barrios, L., Del Nozal, M. J., Bernal, J. L., Jimenez, J. J., Palencia, P. G., Meana, A., 2008. How natural infection by Nosema ceranae causes honeybee colony collapse. Environ. Microbiol. 10, 26592669.

Higes, M., Martín-Hernández, R., García-Palencia, P., Marín, P., Meana, A., 2009. Horizontal transmission of Nosema ceranae (Microsporidia) from worker honeybees to queens (Apis mellifera). Environ. Microbiol. Reports 1, 495-498.

Higes, M., Martin-Hernandez, R., Garrido-Bailon, E., Garcia-Palencia, P., Meana, A., 2007b. Detection of infective Nosema ceranae (Microsporidia) spores in corbicular pollen of forager honeybees. J. Invertebr. Pathol. 97, 76-78.

Keeling, P. J., Fast, N. M., 2002. Microsporidia: biology and evolution of highly reduced intracellular parasites. Ann. Rev. Microbiol. 56, 93-116.

Kralj, J., Fuchs, S., 2010. Nosema sp. influences flight behavior of infected honey bee (Apis mellifera) foragers. Apidologie 41, 21-28.

Laidlaw, J. H. H., Page, R. E., 1997. Queen rearing and bee breeding. Cheshire: Wicwas Press

Ledoux, M. N., Winston, M. L., Higo, H., Keeling, C. I., Slessor, K. N., LeConte, Y., 2001. Queen and pheromonal factors influencing comb construction by simulated honey bee (Apis mellifera L.) swarms. Insect. Soc. 48, 14-20.

Li, Z., Zhang, S., Liu, Q., 2008. Vitellogenin functions as a multivalent pattern recognition receptor with an opsonic activity. PLoS ONE 3, e1940. 


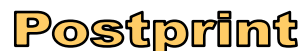

Version définitive du manuscrit publié dans / Final version of the manuscript published in : Journal of Invertebrate Pathology, 2011, vol.106, n³, DOI : 10.1016/j.jip.2010.12.005

Li, Z., Zhang, S., Zhang, J., Liu, M., Liu, Z., 2009. Vitellogenin is a cidal factor capable of killing bacteria via interaction with lipopolysaccharide and lipoteichoic acid. Mol. Immunol. 46, 3232-3239.

Lin, H., Winston, M. L., Haunerland, N. H., Slessor, K. N., 1999. Influence of age and population size on ovarian development, and of trophallaxis on ovarian development and vitellogenin titers of queenless worker honey bee (Hymenoptera: Apidae). Can. Entomol. 131, 695-706.

Liu, Q.-H., Zhang, S.-C., Li, Z.-J., Gao, C.-R., 2009. Characterization of a pattern recognition molecule vitellogenin from carp (Cyprinus carpio). Immunobiology 214, 257-267.

Liu, T. P., 1992. Oocytes degeneration in the queen honey bee after infection by Nosema apis. Tissue Cell 24, 131-8.

Maisonnasse, A., Alaux, C., Beslay, D., Crauser, D., Gines, C., Plettner, E., Le Conte, Y., 2010. New insights into honey bee (Apis mellifera) pheromone communication. Is the queen mandibular pheromone alone in colony regulation? Front. Zool. 7, 18.

Malone, L. A., Gatehouse, H. S., 1998. Effects of Nosema apis infection on honey bee (Apis mellifera) digestive proteolytic enzyme activity. J. Invertebr. Pathol. 71, 169-174.

Malone, L. A., Giacon, H. A. and Newton, M. R. 1995. Comparison of the responses of some New Zealand and Australian honey bees (Apis mellifera L) to Nosema apis Z. Apidologie, 26, 495502 .

Mayack, C., Naug, D., 2009. Energetic stress in the honeybee Apis mellifera from Nosema ceranae infection. J. Invertebr. Pathol. 100, 185-8.

Naug, D., Gibbs, A., 2009. Behavioral changes mediated by hunger in honeybees infected with Nosema ceranae. Apidologie 40, 595-599.

Nelson, C. M., Ihle, K. E., Fondrk, M. K., Page, R. E., Jr., Amdam, G. V., 2007. The gene vitellogenin has multiple coordinating effects on social organization. PLoS Biol. 5, 673-677.

Page, R. E., Jr., Amdam, G. V., 2007. The making of a social insect: developmental architectures of social design. Bioessays 29, 334-43.

Pan, M. L., Bell, W. J., Telfer, W. H., 1969. Vitellogenic blood protein synthesis by insect fat body. Science 165, 393-4.

Pankiw, T., Winston, M. L., Plettner, E., Slessor, K. N., Pettis, J. S.,Taylor, O. R., 1996. Mandibular gland components of European and Africanized honey bee queens (Apis mellifera L). J. Chem. Ecol. 22, 605-615.

Paxton, R. J., Klee, J., Korpela, S., Fries, I., 2007. Nosema ceranae has infected Apis mellifera in Europe since at least 1998 and may be more virulent than Nosema apis. Apidologie 38, 558565.

Plettner, E., Otis, G. W., Wimalaratne, P. D. C., Winston, M. L., Slessor, K. N., Pankiw, T., Punchihewa, P. W. K., 1997. Species- and caste-determined mandibular gland signals in honeybees (Apis). J. Chem. Ecol. 23, 363-377. 


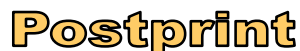

Version définitive du manuscrit publié dans / Final version of the manuscript published in : Journal of Invertebrate Pathology, 2011, vol.106, n³, DOI : 10.1016/j.jip.2010.12.005

Raikhel, A. S., Kokoza, V. A., Zhu, J., Martin, D., Wang, S.-F., Li, C., Sun, G., Ahmed, A., Dittmer, N., Attard, O. G., 2002. Molecular biology of mosquito vitellogenesis: from basic studies to genetic engineering of antipathogen immunity. Insect Biochem. Mol. Biol. 32, 1275-1286.

Richard, F. J., Tarpy, D. R., Grozinger, C. M., 2007. Effects of insemination quantity on honey bee queen physiology. PLoS ONE 2, e980.

Ricks, B. L., Vinson, S. B., 1972. Changes in nutrient content during one year in workers of the imported fire ant. Ann. Entomol. Soc. Am. 65, 135-138.

Rinderer, T. E., Sylvester, H., A 1978. Variation in response to Nosema apis, longevity, and hoarding behavior in a free-mating population of the honey bee. Ann. Entomol. Soc. Am. 71, 372-374.

Seehuus, S. C., Norberg, K., Gimsa, U., Krekling, T., Amdam, G. V., 2006. Reproductive protein protects functionally sterile honey bee workers from oxidative stress. Proc. Natl. Acad. Sci. USA 103, 962-7.

Slessor, K. N., Winston, M. L., Le Conte, Y,. 2005. Pheromone communication in the honeybee (Apis mellifera L.). J. Chem. Ecol. 31, 2731-45.

Tanaka, E. D., Hartfelder, K., 2004. The initial stages of oogenesis and their relation to differential fertility in the honey bee (Apis mellifera) castes. Arthropod Struct. Dev. 33, 431-442.

Tong, Z., Li, L., Pawar, R., Zhang, S., 2010. Vitellogenin is an acute phase protein with bacterialbinding and inhibiting activities. Immunobiology in press, doi:10.1016/j.imbio.2009.10.001

Toth, A. L., Robinson, G. E., 2005. Worker nutrition and division of labour in honeybees. Anim. Behav. 69, 427-435.

van Engelsdorp, D., Hayes, J., Jr., Underwood, R. M., Pettis, J., 2008. A survey of honey bee colony losses in the U.S., fall 2007 to spring 2008. PLoS ONE 3, e4071.

Wang, D. I., Moeller, F. E., 1970. The division of labor and queen attendance behavior of Nosema infected worker honeybees. J. Econ. Entomol. 63, 1539-1541.

Webster, T. C., 1993. Nosema apis spore transmission among honey bees. Am. Bee J. 133, 869-870.

Webster, T. C., Pomper, K. W., Hunt, G., Thacker, E. M., Jones, S. C., 2004. Nosema apis infection in worker and queen Apis mellifera. Apidologie, 35, 49-54.

Wheeler, D. E., Kawooya, J. K., 1990. Purification and characterization of honey bee vitellogenin. Arch. Insect Biochem. Physiol., 14, 253-67.

Williams, J. B., Roberts, S. P., Elekonich, M. M., 2008. Age and natural metabolically-intensive behavior affect oxidative stress and antioxidant mechanisms. Exp. Gerontol. 43, 538-49.

Zander, E., 1909. Tierische Parasiten als Krankenheitserreger bei der Biene. Münch. Bienenzeitg. 31, 196-204. 


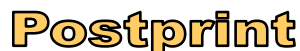

Version définitive du manuscrit publié dans / Final version of the manuscript published in : Journal of Invertebrate Pathology, 2011, vol.106, n³, DOI : 10.1016/j.jip.2010.12.005

\section{Figure legends}

Figure 1. Pathological effects of $N$. ceranae on different queen physiological parameters (mean $\pm \mathrm{SE}$ ). The levels of lipid store in the fat bodies (A), Vg titer in hemolymph (B) and total antioxidant capacities in the whole abdomen (C) between control and infected queens were compared using MannWhitney $\mathrm{U}$ tests. Sample size is indicated in each bar.

Figure 2. Pathological effects of $N$. ceranae on QMP levels in queen heads (mean $\pm \mathrm{SE}$ ). The levels of 9-ODA, HVA 9-HDA and HOB ( $\mu \mathrm{g} / \mathrm{head})$ between control $(n=9$, white bar) and infected queens $(n=$ 10 , grey bar) were compared using Mann-Whitney U tests.

Table 1. Correlation analysis between the different queen physiological parameters (lipid store in the fat bodies, Vg titer in hemolymph and QMP levels (9-ODA, HOB and 9-HDA) in heads). $r$ values are shown in the table. Number in bold indicates a significant correlation between lipid store and $\mathrm{Vg}$ titer $(P=0.013)$. The others parameters are not significantly correlated $(P>0.05)$.

\begin{tabular}{lcccc}
\hline Parameters & Lipid store & Vg titer & 9-ODA & HOB \\
\hline Vg titer & $\mathbf{- 0 . 6 0 4}$ & & & \\
9-ODA & 0.161 & 0.089 & & \\
HOB & -0.134 & -0.290 & -0.385 & \\
9-HDA & -0.168 & 0.265 & 0.066 & -0.215 \\
\hline
\end{tabular}




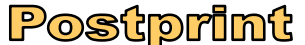

Version définitive du manuscrit publié dans / Final version of the manuscript published in : Journal of Invertebrate Pathology, 2011, vol.106, n³, DOI : 10.1016/j.jip.2010.12.005

A

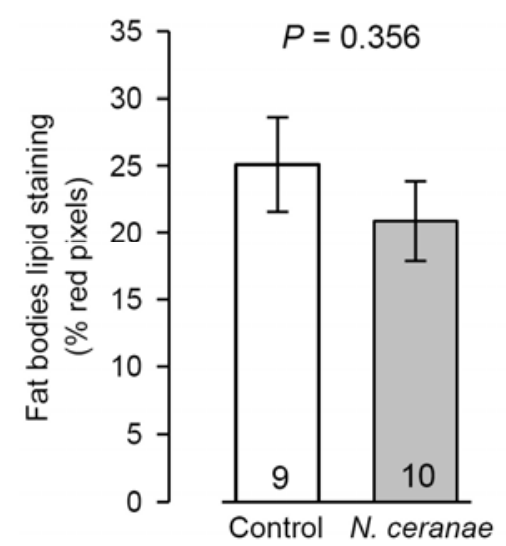

B

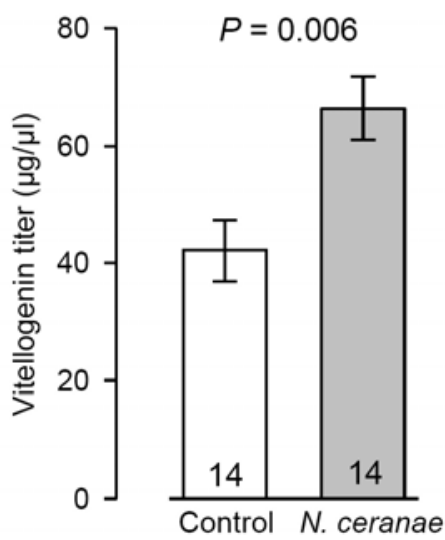

C

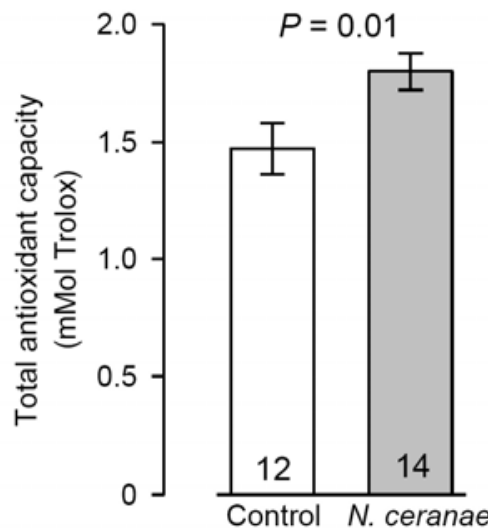

Figure 1
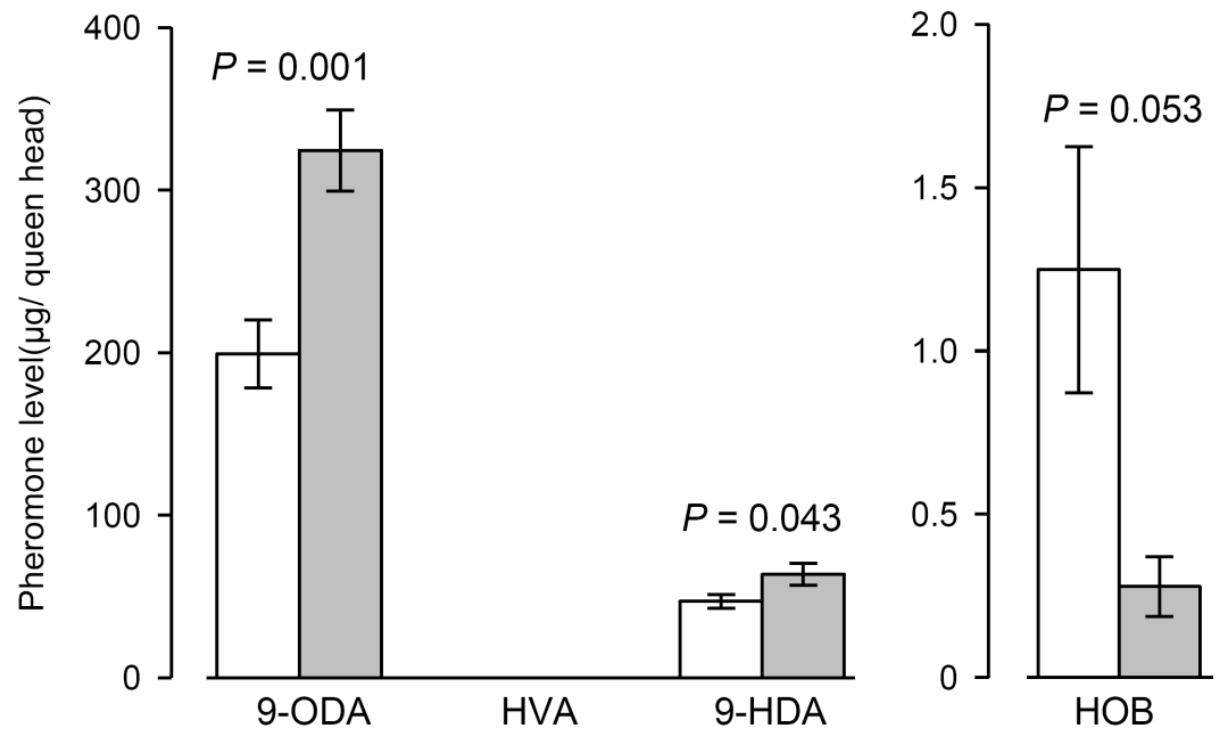

Figure 2 